\title{
STUDI KHASIAT DAUN KATU (SAUROPUS ANDROGYNUS) DALAM MENGATASI KERACUNAN ION TEMBAGA BERDASARKAN GAMBARAN HISTOPATOLOGI OVARIUM TIKUS BETINA
}

\section{DISERTASI}

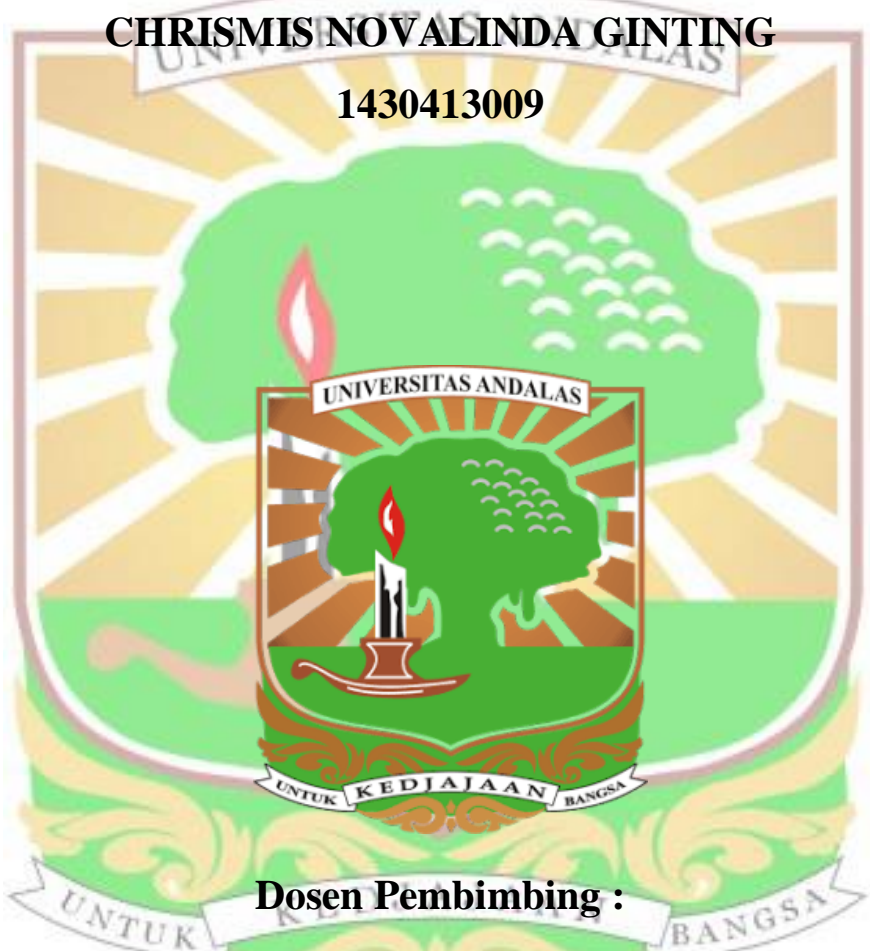

Ketua : Prof. Dr. Rahmiana Zein

Anggota : Prof. Dr. Almahdy

Anggota : Dr. Ety Yerizel

PROGRAM PASCASARJANA

UNIVERSITAS ANDALAS

2017 


\title{
STUDI KHASIAT DAUN KATU (SAUROPUS ANDROGYNUS) DALAM MENGATASI KERACUNAN ION TEMBAGA BERDASARKAN GAMBARAN HISTOPATOLOGI OVARIUM TIKUS BETINA
}

\author{
Chrismis Novalinda Ginting Rahmiana Zein Ety Yerizel, Almahdy
}

\begin{abstract}
ABSTRAK
Kemampuan daun S.androgynus sebagai biosorben ion $\mathrm{Cu}(\mathrm{II})$ dari larutan berair diuji dengan menggunakan metode Batch. Hasil penelitian menunjukkan bahwa kapasitas adsorpsi daun $\mathrm{S}$.androgynus diperoleh pada $\mathrm{pH} 4$ dengan konsentrasi awal ion $\mathrm{Cu}$ (II) $1500 \mathrm{mg} / \mathrm{L}$, dosis biosorben $0.1 \mathrm{~g}$ dan waktu kontak 15 menit. Pengujian dengan model isoterm Langmuir dan Freundlich menunjukkan nilai R2 0.9879 dan 0.9263. Hasil analisis FTIR menunjukkan terjadi pergeseran pada pita hiroksil $(\mathrm{OH})$ dan karbonil (CO). Analisa SEM menunjukkan bahwa permukaan daun S.androgynus mempunyai permukaan yang berpori, berlekuk dan kasar. Pra perlakuan dengan antidote S.adrogynus sebelum dipaparkan dengan ion $\mathrm{Cu}(\mathrm{II})$ dapat menurunkan kadar SGOT, SGPT, urea, kreatinin dan MDA sebanyak 16,11\%; 64,38\%; 28,51\%; 50\% dan $38,7 \%$ secara berturut-turut. Pra perlakuan dengan daun S.androgynus dapat mengurangi derajat kerusakan organ ovarium tikus percobaan.
\end{abstract}

Keywords: biosorpsi, $\mathrm{Cu}(\mathrm{II})$, daun katu, ovarium

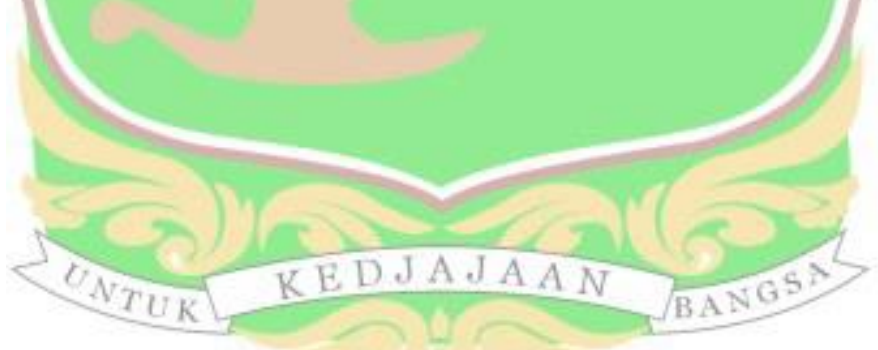




\title{
UTILIZATION STUDY OF SWEET LEAVES (SAUROPUS ANDROGYNUS) TO RESOLVE COPPER ION POISONED BASED ON HISTOPATHOLOGY OF FEMALE RAT OVARY DESCRIPTION
}

\author{
Chrismis Novalinda Ginting, Almahdy, Ety Yerizel, Rahmiana Zein
}

Adsorption using natural sources is one of the methods to remove copper in the water body. This research used sweet leaves (Sauropus androgynous) as biosorbent based on the batch system. The result showed that S.androgynus leaves achieved optimum condition at $\mathrm{pH} \mathrm{4}$, the initial concentration of $\mathrm{Cu}(\mathrm{II}) 1500 \mathrm{mg} / \mathrm{L}$, mass $0.1 \mathrm{~g}$ and contact time 15 minutes. Deternination coefficient (R2) of Langmuir and Freundlich model were 0.9879 and 0.9263 . The shifting of the hydroxyl group and carbonyl group revealed that adsorption process has been taken place on S.androgynus. SEM micrograph indicated the folded roughly and porous supporting adsorption process. In this research also tested the ability of S.androgynus to protect rat ovary against $\mathrm{Cu}$ (II) toxicity and biochemical parameters of serum. Group with antidote pretreatment first before exposed to $\mathrm{Cu}(\mathrm{II})$ decrease SGOT, SGPT, urea, creatinine and MDA level as much as $16,11 \% ; 64,38 \% ; 28,51 \% ; 50 \%$ and $38,7 \%$, respectively. In general, pretreatment with S.androgynus leaves could decrease ovary damage.

Keywords : biosorption, cooper, sauropus androgynus, ovary

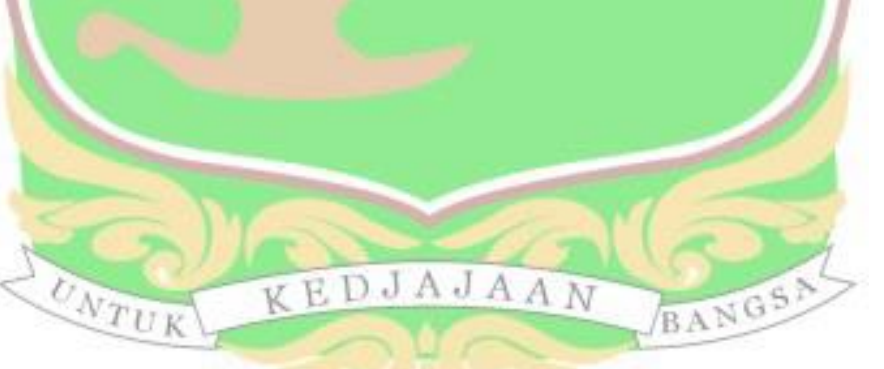

